\title{
The African Paradise of Cardinal Carvajal: New Light on the "Kunstmann II Map," 1502-1506
}

\author{
ALESSANDRO SCAFI \\ The Warburg Institute
}

Le symbole du paradis que l'on voit sur la carte géographique du monde « Kunstmann II » (1502-1506) offre à l'historien un point de départ remarquable pour l'exploration des idées européennes sur un paradis terrestre en Afrique et des perceptions européennes de l'Afrique aux environs de 1500 . Une analyse attentive de l'iconographie de cette carte met en lumière son contexte et ses objectifs. Les armoiries présentes sur le grand arbre du paradis appartiennent au cardinal espagnol Bernardino López de Carvajal (1456-1523), ambassadeur del'Espagne auprès du pape. Carvajal, qui a joué un rôle important dans le cadre du traité de Tordesillas, était un partisan convaincu d'une nouvelle croisade contre l'Islam en Afrique et au Moyen Orient qui visait la reconquête de Jérusalem et l'expansion de la foi chrétienne dans le monde.

The manuscript map of the world known as "Kunstmannn II" (one of a set of 1 thirteen charts published by Friedrich Kunstmann in 1859) first caught my attention as an example of late medieval maps on which the earthly paradise (or Garden of Eden) is located in Africa rather than in the Far East (Figures 1, 2, and 3). ${ }^{1}$ Such a location is consistent with the contemporary debate about a southern paradise, but the more one looks at the map sign itself, the more intriguing it becomes. In this essay the remarkable iconography of paradise on the Kunstmann II world map will serve as a basis for the analysis of European ideas of an earthly paradise in Africa, as well as of European perceptions of Africa around 1500. By looking at the detail of paradise (and at its relationship with some other special features on the map), new light can be shed on the map's context and original purpose. It will be seen that the Kunstmann II map bears witness to the renewed alliance between the pope and the Spanish sovereigns during the first years of the sixteenth century. The map can also be associated with the intimate convergence of the discovery of the New World and the promotion of a new crusade to spread the Christian faith throughout Africa, and indeed throughout the whole earth.

The Kunstmann II map ( $99 \times 110.5 \mathrm{~cm})$ records the discoveries made in the New World by Miguel Corte-Real and Amerigo Vespucci in 1501-1502. Consequently, it 
has hitherto usually been studied as an important early document for the history of the discovery of America, and compared with other early depictions of the New World. The anonymous map has been dated to between 1502 and 1506, which would make it one of the earliest European world maps to show the New World as well as one of the last European world maps to feature the earthly paradise. The map covers Asia, Europe, Africa, and the newly discovered Americas. We see Greenland (Terra de lavorador) depicted in the shape of a long and narrow island, stretching from east to west. Newfoundland and Labrador, designated as Terra de Corte-Reall, appear as a group of islands and are joined by four finger-like strips, which have given the chart its nickname of "Four-Finger Map." Cuba (Terra de Kuba) and Haiti (insula Spagnola) are depicted as large islands. For South America the coastline is shown from San Lorenzo, on the Gulf of Maracaibo, to the mouth of the Orinoco, and, after a gap, from Cape San Roque to Rio Cananea, matching the information provided by Vespucci's expedition of 1501-1502. An inscription and a representation in South America register the local phenomenon of cannibalism, also reported by Vespucci. ${ }^{2}$

Since the map's discovery and publication in the nineteenth century, scholars have focused their attention mainly on its western part, seeing it as essentially a document for the history of discoveries that were usually described in terms of the progressive development from the medieval "dark ages" to the radiant "dawn of modern geography." Thus, in his 1859 atlas, Kunstmann thought it sufficient to reproduce only the western part of the map, as did Jules-Théodore-Ernest Hamy and Konrad Kretschmer, in 1886 and 1892 respectively. ${ }^{3}$ If some scholars have also glanced at the representation of Africa (Figure 2), it has only been to notice its exaggerated east-west extension (due to the inaccurate calculation of longitude), to compare coastal place names with those on other charts or other records of Portuguese voyages of exploration, or to conclude from the absence of Madagascar, discovered in 1506, that the chart must have been made before that date.

Little attention has been paid to the map sign for the earthly paradise (10 $\mathrm{x}$ $7 \mathrm{~cm}$ ) that appears in the middle of southern Africa (Figure 3). The presence of paradise in Africa has not gone entirely unremarked, but it has not been discussed. Recently, for example, Hans Wolff and Ivan Kupčic have noted a "pictorial symbol of paradise" in Africa without, however, expanding on the matter. ${ }^{4}$ Rather more words are devoted to it in an Italian study published in 2001, significantly entitled Alla scoperta del mondo, where the presence of paradise in Africa is defined as a "very solid anchorage to the past" and "very peculiar on a map of that period." The authors suggest the position of the vignette is modelled on the representation of paradise 
on the Estense Catalan map of 1450-1460.5 A few scholars have shown interest in the Kunstmann II map for its depiction of paradise in Africa, but the references are brief and limited to generalities. ${ }^{6}$ Yet, there is much to learn by looking more closely at this intriguing African feature.

\section{Approximations to Paradise in Africa}

The representation of Africa on the Kunstmann II map traces the coastline in careful detail, and is rich in names of bays, promontories, rivers, cities, and ports. The portrayal of the interior is more summary, the general emptiness of the continent being masked by seven portraits of local rulers and a large vignette on the Tropic of Capricorn showing paradise, labelled paradisus terrestris. ${ }^{7}$

The inclusion of the Garden of Eden on a world map dating from just after 1500 and including cartographical sketches of the New World is indeed remarkable. Throughout the Middle Ages the Garden of Eden described in Genesis was believed to exist on earth, as a place belonging both to the past and to the east. In the Hebrew version of Genesis, the Garden of Eden is described as being placed miqedem, a term that refers to both time and space: the garden is both "at the beginning" and "in the east" (2.8). Translators had to choose between rendering the Hebrew temporally or spatially, but from a geographical point of view, exegetes held that the original dwelling place of Adam was located in the farthest east, as indicated in the old Latin translation of Genesis, the Vetus Latina. By about 1500, however, it had become increasingly difficult to maintain the idea of a surviving paradise in the light of contemporary geographical knowledge. ${ }^{8}$ The notion of an African paradise as an alternative to the eastern, Asian location is the last episode of a thrilling series of speculations and controversies that had been part of the European debate about the geographical aspects of the biblical paradise narrative since the thirteenth century. The locating of paradise somewhere in a still largely unknown Africa, rather than in Asia, which was being increasingly explored by Europeans, was a development of the idea that paradise was situated either on the equator or south of it, with the torrid zone understood to be the fiery sword of the Cherubim guarding the entrance to Eden (Genesis 3.24). A number of factors had led to this view. The Nile, long identified as one of the rivers of paradise (the Gihon) was known to flow through Africa, and the land of Cush - that Genesis described as encircled by the Gihon (2.13) — had been identified with Ethiopia since Jerome's translation of the Bible in the fourth century. It was Jerome too who had opted for a temporal rather than a spatial rendering of the Hebrew word miqedem, making 
the text indicate that God had planted paradise "in the beginning" instead of "in the east." In the fourteenth century, Duns Scotus took issue with the designation "in the east," arguing that "east" was a relative notion that depended on the position of the observer and that consequently paradise could be located anywhere and not necessarily—or not only—in eastern Asia. ${ }^{9}$

The two lands mentioned in Genesis as neighbouring paradise, Havilah and Cush $(2.11,13)$, were understood as regions in India and Ethiopia respectively. India and Ethiopia had already been closely associated in the Greco-Roman geographical tradition. Moreover, throughout the Middle Ages Ethiopia was considered part of the vast and mysterious region of India. From Late Antiquity onwards, various texts associated the biblical paradise and its rivers with Ethiopia or pointed to the eastern provenance of the Nile. ${ }^{10}$ About 1330, for example, a Dominican missionary, Jordan of Sévérac, suggested that paradise could lie between India tertia and Ethiopia, the land of Prester John, the legendary Christian priest-king who, it was believed, ruled over a vast and fabulous empire beyond Muslim reach. ${ }^{11}$ The traditional association of the earthly paradise with Prester John arose from an immensely popular and much-translated, but entirely fictitious, letter that had supposedly been sent by Prester John to the Byzantine emperor Manuel I Comnenus (1143-80), in which Prester John related that in one of his lands there was a marvellous spring at three days' journey from the earthly paradise. ${ }^{12}$ At first, Prester John's kingdom was thought to be somewhere in India, but in the course of the fourteenth century his empire was gradually moved from India to Ethiopia, a land that had always been perceived as almost celestial. ${ }^{13}$ This transfer was yet another factor contributing to the late medieval location of paradise in Africa. It also explains why, on the Kunstmann II map, paradise appears near the portrait of Prester John (Figures 2 and 3). ${ }^{14}$

Modern scholars should not forget that the earthly paradise of the Holy Scriptures was always believed to lie outside the inhabited and known world. Thus, the idea of an "African paradise" was acceptable precisely because the African regions known to man were considered to border on an inaccessible "beyond" in which paradise lay. The distinction between the accessible part of the earth and that part which was specifically out of bounds to humankind is crucial to the understanding of early travel accounts. Failure to appreciate that no medieval Christian would have presumed to think he could reach, let alone enter, the earthly paradise has led modern scholars to misinterpret some of their sources and to over-simplify, even distort, what they have taken to be "testimonials" to an African paradise. An early supposed authority for a southern African paradise is the anonymous Libro del conosçimiento (c. 1350-60), but it says less than has been thought: the unknown 
Spanish author is reporting a theory that he has heard and does not necessarily endorse it. ${ }^{15} \mathrm{He}$ also reports other things about paradise, such as that it is situated on an exceptionally high mountain that reaches up as far as the sphere of the moon, that nobody has climbed the mountain, and that paradise has been seen variously in the east and in the south according to the position of the sun in the Zodiac. ${ }^{16}$ Another often misunderstood source is the fifteenth-century account of the discovery and conquest of Guinea, in West Africa, preserved in the Chronica do Descobrimento e Conquista de Guiné of 1453. Its author is the Portuguese chronicler Gomes Eanes de Zurara. He is usually taken to suggest a paradise located in Guinea. Here again a closer reading shows that, like the anonymous Spaniard, Zurara is only reporting a tale: when the Portuguese explorer Gomes Pires declared his intention, in 1445, to lead an expedition into the "country of the Blacks" to explore the course of the river Senegal (thought to be a branch of the Nile), one of his followers replied that he was ready to follow Pires "even to the earthly paradise!"17

Another fifteenth-century traveller, or supposed traveller, the German Arnold von Harff, wrote a fictitious account of a pilgrimage he claimed he had made to Jerusalem between 1471 and 1505 (the Pilgerfahrt). Von Harff is usually cited as a promoter of the notion that paradise was located on the African Mountains of the Moon (the mountains that give rise, according to Ptolemy, to the river Nile), but what we in fact learn from his account is that it was Von Harff's wish to find the sources of the Nile and that, when he had discovered them on the Mountains of the Moon, he found no paradise there. ${ }^{18}$ Finally, mention may be made of the work of the Augustinian theologian Jacob Pérez de Valencia (Expositiones in Psalmos Davidicos, 1484), which is also invoked as evidence for the fifteenth-century belief that the site of paradise was on the Mountains of the Moon. ${ }^{19}$ Pérez's topic is the structure of the earth as a sequence of mountains and valleys (for which he combines Ptolemaic theories and the Biblical narrative). He notes that, in the opinion of some, paradise is situated on the Mountains of the Moon, the highest point of one of the five main mountain ranges of the earth. ${ }^{20}$ His own view is that God assigned to Adam the entire southern hemisphere as a wonderful paradise. ${ }^{21}$ Nowhere does he make his own the view that paradise is situated on the Mountains of the Moon.

It is true that the early medieval idea that the earthly paradise could be situated on the peak of a very high mountain might have encouraged late medieval scholars to associate the site of paradise with the Mountains of the Moon. Such an association, however, would have been valid only as long as Ptolemy's mountain ranges remained outside the known regions of the earth. For Pérez, the Mountains of the Moon were the southernmost known part of Africa. ${ }^{22} \mathrm{He}$ mentions the Mountains of the 
Moon only as the place where the Nile resurfaces after disappearing underground, as did the other rivers of paradise, near the Tropic of Capricorn. Paradise was for Pérez in the inaccessible reaches of the southern hemisphere. He understood the flaming sword guarding paradise mentioned in Genesis as a line of fire produced by the intense heat along the Tropic of Capricorn preventing anybody from reaching paradise. It is worth noting that the author of the Kunstmann II map placed his African paradise exactly on the line of the Tropic of Capricorn, thus inviting us to suppose that he had read, or was aware of, Pérez's work, which, as the numerous reprintings show, was still being read in the early sixteenth century.

Pérez is also quoted in Duarte Pacheco Pereira's Esmeraldo de situ orbis (1505-8), described by its author as a book "of cosmography and navigation." Pereira was a Portuguese military leader, distinguished sailor, and man of science. He quotes Pérez on the question of the size of the earth and the sea, calling him "an excellent scholar and master of sacred theology." 23 In the twenty years between the first edition of Pérez's Expositiones and Pereira's Esmeraldo de situ orbis, new lands and seas had been discovered. Pérez himself was aware that Spanish and Portuguese sailors were venturing on the waves of new oceans and discovering new lands to the west and south of the Old World. ${ }^{24}$ The author of the Kunstmann II map placed his sign for paradise on the tropic that Pérez had said was the impassable frontier of fire protecting paradise; the map maker, however, was also outlining and naming on his map several newly discovered lands lying to the south of that tropic, not only in America but also in Africa itself. A legend on the map to the south of the Gulf of Guinea (and thus of the Tropic of Capricorn), for instance, indicates the island where Portuguese criminals were exiled. By the time the Kunstmann II map was compiled, in other words, the known world had been extended to the south of the Tropic of Capricorn at a number of points, almost surrounding, as it were, the unknown African territories thought to border on paradise. The map sign for paradise, however, is intended not to pinpoint an exact location, but to indicate in a general fashion a neighbourhood and a limit, the point at which the known and knowable world was supposed to end. In so far as the author of the Kunstmann II map depicts the coastlines in great detail, enumerates the ports, and defines space by mathematical astronomy, he is adopting the principles of nautical chart making and Ptolemaic mapping. In so far as he includes the inaccessible "somewhere" of the earthly paradise in Africa, he remains in the tradition of the medieval world maps in which the articulation of space is an unfolding of the process of human history and places are indicated next to each other, irrespective of "correct" distances and positions. $^{25}$ 


\section{A European Coat of Arms in the African Paradise}

What makes the representation of paradise on the Kunstmann II map particularly interesting is its design. To read most of the legends and vignettes, the map has to be turned so that east is at the top. The icon and the inscription for paradise (paradisus terrestris) are positioned to be read with the map this way up. The vignette shows paradise on the top of a high mountain, creating an image that evokes the intermediate situation of a paradise on earth halfway to heaven. Paradise is also depicted as a garden protected by a walled enclosure, a standard practice in the iconography of the subject. Within the garden, the larger, central tree could be either the Tree of Life or, more likely, the Tree of Knowledge of Good and Evil, mentioned in Genesis as situated in the middle of Eden, whereas the two small trees flanking it represent the other trees (Genesis 9). On top of the central tree sits a parrot.

The first appearance of a parrot on maps (the Ebstorf mappa mundi of c. 1235-40) placed the bird in India, possibly in recognition of Pliny's description of the parrot as an Indian bird. ${ }^{26}$ In general, parrots are not rare on maps from the age of exploration, and explorers such as Christopher Columbus and Pedro Cabral comment on the great number of parrots among the abundance of birds they observed in the New World. ${ }^{27}$ Portuguese sailors and traders also found parrots in Africa, and brought many colourful birds back to Europe. What may at first sight seem surprising about the parrot on the Kunstmann II map is not that it is in Africa, but that it is in an African paradise. In fact, tradition associated the parrot with the Garden of Eden. It was a bird that had long been praised for its beauty and for its rarity, and medieval bestiaries were only echoing the praise of ancient writers when they wrote of its intelligence and power of speech. ${ }^{28}$ For early Christians, the parrot merited a place in the Garden of Eden as harbinger of the Virgin Mary, the New Eve. Where ancient writers recounted how, after the battle of Actium, a parrot greeted the victorious Augustus in 27 with the words Ave Caesar, medieval Christians took the story as a prefiguration of Christ's virgin birth; Ave Caesar became Ave Maria. Instead of greeting a Roman emperor, the parrot was now greeting the Virgin Mary, the new Eve (Ave in reverse). ${ }^{29}$ In the Garden of Eden, the parrot witnesses Eve being seduced by the devil, and accepting the apple, and announces the New Eve who will bear Christ, by saying: Ave Maria! Dürer's well-known engraving of Adam and Eve in the Garden of Eden also features a parrot. ${ }^{30}$

Most intriguing of all, however, is the coat of arms hanging on the larger tree of paradise. A coat of arms is a sign of ownership. The coat of arms is that of the Spanish cardinal Bernardino López de Carvajal (1456-1523), and the implication 
must be that either the map was once in the cardinal's possession or, more likely, given contemporary cartographic practice, that it had been made for him. ${ }^{31}$ In Tivoli, where Carvajal had the palace of the governors restored, the entrance to the former convent of Santa Maria Maggiore (today the entrance of the Villa d'Este) still features his coat of arms (Figure 4a). From 1495 until 1511 (the time of his participation in the schismatical Council of Pisa) Carvajal was titular cardinal of the Roman Basilica of Santa Croce in Gerusalemme, where other reproductions of his coat of arms can be found in the carvings at, for example, the bottom of his tomb (Figure $4 b$ ).

There was nothing unusual in a cardinal owning a map. In his De cardinalatu, composed in the early sixteenth century, Paolo Cortesi recommended that a mappa mundi, including "its parts which have recently become known through the daring circumnavigations accomplished by our people," should always decorate a cardinal's palace..$^{32}$ But Carvajal was an important diplomat, particularly well-connected. From 1485 to 1488 he had been papal nuncio in Spain, and at the time of the compilation of the map he was King Ferdinand v of Aragón's and Queen Isabella of Castilla and León's ambassador to the pope. ${ }^{33}$ It is not surprising, then, to find the coat of arms of Spain's envoy to Rome on a map showing the New World that was in the process of being "discovered." It is likely that the news of Columbus's discoveries that had reached Ferdinand and Isabel in March 1493 was conveyed to Pope Alexander VI through Carvajal. In June 1493, on Alexander's accession, Carvajal, as ambassador of the Catholic Majesties in Rome, gave an oration, which was immediately printed, containing one of the earliest references to the discovery of the New World, made only five months after Columbus's return. ${ }^{34}$ Carvajal also played an important role in the protracted negotiations leading to the treaty of Tordesillas, with which Spain and Portugal settled their rival claims over the New World. ${ }^{35}$ In fact, it was precisely for his role in negotiating the treaty that Carvajal was promoted to the cardinalate, on September 20, 1494, a promotion strongly recommended by Queen Isabella. ${ }^{36}$

Whereas the geographical outlines of the map illustrate Columbus's and Vespucci's discoveries, the vignette on the Iberian peninsula of two figures, labelled Rex Hispaniae and Rex Portugalie, shaking hands, are a clear reference to the treaty of Tordesillas (see Figure 2, top left). The line of demarcation specified in the treaty is recorded on this map as on many contemporary charts. The two pairs of sailing boats placed in the western and southern Atlantic, as if to suggest the direction of ongoing voyages of discovery, may also be interpreted as a hint at Spanish and Portuguese explorers reaching lands to the west and east of the line respectively. 


\section{Mapping a Christian Africa}

The Kunstmann II map is not only about territorial claims. By displaying the geographical knowledge of his time, the author of the map also provides a coherent and unitary vision of the spread of European Christianity over the earth. As Paolo Capello, the Venetian ambassador in Rome, wrote in 1500, Carvajal was a keen supporter of the idea of a new crusade against the infidels. ${ }^{37}$ In Carvajal's view, the defeat of Moorish rule in the Iberian Peninsula had been possible thanks to the strength of the Christian faith and to the simple fact that Spanish troops were more a religious congregation than a multitude of soldiers. Christianity was destined to prevail and Christians were called to inherit dominion over the whole earth, a dominion that had been held by Rome and by Charlemagne and that was now passing to Spain. After the reconquista in Iberia, their Catholic Majesties were ready to fight Islam in Africa and the Middle East. ${ }^{38}$ The Spanish cardinal expoused the widespread prophetic tendency to see the reconquista (completed with the fall of Granada in 1492) as a prefiguration of the reconquest of Jerusalem and the spread of the Christian faith throughout the earth. The election of Alexander vi Borgia in 1492 was greeted by Carvajal, in his Oratio super praestanda solemni obedientia, as a decisive turning point. With the Spanish monarchs called to conquer the earth, and a Spanish pontiff, shepherd and lord of the entire world, called to reform the Church and fight the infidels, Spanish dominion was now renewing the universal empire of Rome. Exalting the ancient relationship between Hispania and Rome, Carvajal justified Spanish claims over Africa by referring to the ancient Visigothic rule there. ${ }^{39}$ In 1496, Carvajal conveyed to Ferdinand and Isabella Alexander vi's decision to grant them the title of "Catholic Majesties" in recognition of their efforts to defend the church and fight the enemies of Christ both in Spain and in Africa. ${ }^{\circ}$

Carvajal played an important role in the Spanish policy in Africa. In 1494 he countered Portuguese complaints at the papal concession to Spain of the kingdom of Fez, by arguing that the Spanish monarchs were the legitimate heirs of the Roman empire and therefore had full rights to the African conquest. With the bull Ineffabilis et summi (February 13, 1495), again negotiated by Carvajal, Alexander vi granted to the Spanish kings the right to conquer any land they wished in Africa. The pope explained his decision on the basis of the historical rights of the Visigoths, the good deeds performed by the Spanish kings, and expressed the hope that a swift conquest of Africa would spread there the name of Christ, the necessary step towards the liberation of the Holy Land. Many preachers in Rome urged the Catholic Majesties 
to christianize Africa, for example gaining back for Christianity the city of Tagaste, the birthplace of the great Augustine. ${ }^{41}$

Even though, according to some historians, Spanish claims over Africa were part of a strategy that aimed at countering Portuguese opposition to Spanish Atlantic expansion, it is worth noting that in her will, composed in 1504, Queen Isabella was still stressing the importance of the conquest of Africa and of the fight to propagate Christian faith, and that, after her death in 1505, Ferdinand continued the African military campaign. Carvajal even suggested to Alexander vi's successor, Julius II, the establishment of a feast on 1 November (in substitution of All Saints) in commemoration of Ferdinand's victory in Mazalquivir in 1505. Since the discoveries in the West, Ferdinand had been celebrated as the universal ruler and defeater of Islam, capable of subjugating the Ethiopians and all African peoples, and poised to reclaim for the Christian faith the entire Orient, including Jerusalem. ${ }^{42}$

The representation of Africa on the Kunstmann II map owes much to this vision (Figure 2). A number of kings are portrayed in Africa. In his bull Ineffabilis et summi (1495), Alexander vi had pointed out that African territories were ruled by sovereigns all having the title of kings. Most of these kingdoms, however, needed to be Christianized, and the propaganda accompanying Spanish diplomacy presented King Ferdinand as the king capable of propagating the faith by unifying several different kingdoms. ${ }^{43}$ Sapi (Sappi, on the map) was the name given to the people living along the coast of Sierra Leone by Portuguese traders in the fifteenth and sixteenth centuries. The Malindi leader (Rex Melindi on the map) had offered the first Portuguese expedition, led by Vasco Da Gama (1497-1499), hospitality and gifts. Magnus Soldanus was the Sultan of Babylon, who ruled over Egypt and the Holy Land and had special diplomatic ties with the Spanish monarchs. The presence of the king of Tunis (Rex Tunci) and the king of Fez (rex Fessi) (as we have seen, their territories were the object of protracted negotiations between Spain and Portugal) reminded the map viewer that these African cities, which had risen to independent sovereignty, had became very populous after the expulsion of the Moors and Jews from Spain in 1492 and were the object of Ferdinand's military campaign. "Prince Bemoim" (the king, or bumi, of Jolof, Ziloffo on the map), had requested the Portuguese to baptize him along with all his people, as reported in 1488 by João de Barros and Pagholo degli Ulivieri, and was regarded as a good example for the future of African Christianity. ${ }^{44}$ The point is underlined by the presence on the map of the legendary Prester John, the Christian ruler ready to help European Christendom in its fight against Islam. 
In this context, the submission of the Canary islands (insule de canaria) and the new discoveries in the Atlantic were seen by Spain (and by Carvajal) as an important step in the process of the conversion of Africa, a process that had begun with the expulsion of the Muslims from Granada and that aimed at a crusade against the Ottoman Turks and the Christian reconquest of the Holy Land. Indeed, in 1503 Carvajal was named patriarch of Jerusalem. The importance given to the conquest of Jerusalem also explains the visual emphasis given to the holy city (surmounted, on the map, by a standard marked with a cross). Mecca (Mecha), the city from which the heresy of Islam had spread, is also pictured at the eastern edge of the Arabian peninsula.

\section{Africa and the New Lands in the West}

It is the connection in the Kunstmann II map between expansion in Africa and recovery of Jerusalem, on the one hand, and the discovery of new lands beyond the ocean, on the other, that has hitherto been missed. As Columbus wrote to Alexander VI in February 1502, sailing westwards was another path to reach the Holy Land. 45 The clue lies in the design of the earthly paradise in Africa, Carvajal's coat of arms, and the line of Tordesillas running through the "four fingers" in the north and coinciding with the spit on which the cannibal is roasting his victim in the south. Until now, the four finger-like strips have been taken to symbolize the vast unknown mainland of America, green with rich forests. The prominence of such a large feature on the map, however, could suggest another, more arresting meaning. The fingers belong to a right hand, open with the palm facing upwards, as if to invite the European to the New World. A similar gesture is shown, for instance, in the Virgin of the Navigators by Alejo Fernández (painted somewhat later, c. 1530). An earlier visual reference is the famous engraving that accompanied Giuliano Dati's poem L'isola che ha trovato nuovamente il Re di Spagna, published in 1493, where King Ferdinand gestures to Columbus towards the new lands in the west. ${ }^{46}$ Even more pertinent is the Duke of Alba's reference, in 1492, to the "holy hand" of Alexander vi, whom he saw as destined to strengthen the Catholic faith and defeat its enemies. ${ }^{47}$ But it is Carvajal's own Oratio super praestanda solemni obedientia of 1493 that seems to confirm our interpretation of the hand on the Kunstmann II map:

"Christ has put under their authority [of the Spanish kings] also the Fortunate Islands, well known for their wonderful fertility [the Canary Islands are depicted on the map]. Recently, he has also pointed out other unknown islands towards the Indies, which are 
pre-eminently considered among the most precious things on earth and which are expected to obey soon to Christ thanks to the action of royal envoys". ${ }^{8}$

Thus the hand appears to belong to Christ. It is showing the Spaniards the unknown territories that they are to claim for his Church. In such a light we can relate the coincidence in South America of the pole-to-pole Tordesillas line with the cannibal's spit to the whole issue of the expansion of the faith; teaching Christianity also meant spreading civilization. In the bull Inter caetera issued on May 3, 1493, the pope encouraged the Spanish kings to send missionaries to the new lands to teach both the Catholic faith and good customs: the monstrous practice of cannibalism portrayed on the map (not far from the inscription Terra Sanctae Crucis) was a potent reminder of the importance of such a task, confirmed in 1504 by Queen Isabella. ${ }^{49}$

It is reasonable to assume a relationship between the hand pointing to the new lands and the coat of arms in the African paradise, as well as a general cohesion and interrelation of meanings on the map. In his sermon for the election of Alexander vi, Carvajal had already combined heraldic and biblical references, when he emphasized the coincidence between the reconquista of Granada and the election of a Spanish pope. In his view, the verse in Isaiah 11.6, describing the calf and the young lion being led by a little child, was an anticipation of the union of the bull of the Borgia and the lion of Castille, under the auspices of the Christ child..$^{\circ 0}$ It is possible that the author of the map intended to suggest several layers of meaning in a similar vein. A shield hanging on a tree is a frequent motif in heraldry. The custom at tournaments was to present shields and to issue challenges at a "tree of honour". Here, the tree of honour is the Tree of Knowledge in paradise. Carvajal was titular cardinal of Santa Croce in Gerusalemme, and, as recounted by the story of the True Cross, depicted in the apse of that church and extensively quoted by Carvajal in a sermon delivered in 1508 before the Emperor Maximilian, the Tree of Knowledge provided the wood for the cross of Christ..$^{51}$ Famous relics of the Cross were housed in Carvajal's church and the theme of the triumph of the Cross over the infidels was part of Spanish propaganda and enthusiasm for the expansion of the faith. Queen Isabella was compared to the empress Helena, who recovered the Cross in Jerusalem, and Ferdinand with the emperor Heraclius, who entered the holy city with a relic of it. For the Jubilee year of 1500 , Carvajal restored his church and had himself portrayed in the mosaic of the Chapel of Saint Helena, kneeling at the foot of the Cross held by the saint..$^{52}$ So it is fitting that on the map his coat of arms hangs on the wood of the Cross.

The key element of the paradise vignette, however, is the parrot. The parrot was considered, as we have seen, to have been an eye-witness to the Fall and a symbol 
of the virgin birth of Christ. On the Kunstmann II map, however, it could also stand as a symbol of eloquence, another accepted meaning, for a man acclaimed as a gifted orator. ${ }^{53}$ As a matter of fact, another parrot features on the map, shown in the hand of the Sultan of Babylon, the ruler of Egypt (Figure 5). On several late medieval nautical charts the Sultan of Babylon is portrayed with a parrot in his hand. ${ }^{54}$ In other cases, a parrot appears along the Nile. ${ }^{55}$ It is likely that Egypt was considered by Europeans as a land rich in parrots; it was well known, for instance, that a parrot was presented to Frederick II by the Sultan of Babylon. ${ }^{6}{ }^{6}$ The parrot, however, would also symbolize the work of the ambassador, since the parrot imitates the voice of its master. 57 Thus the parrot in the hand of the Sultan of Babylon on the Kunstmann II map could also stand for Peter Martyr d'Anghiera, the ambassador sent in April 1501 by Isabella and Ferdinand to the new Sultan of Babylon, Khansu al-Ghuri. Peter's task was to strengthen the alliance with Egypt against the Turks, guarantee the security of the African coast, and negotiate on improvement in the conditions of the local Christian community as well as access to the Holy Places. ${ }^{58}$ This would be a confirmation that the author of the map intended the parrot to imply, as one of its meanings, the mission of the ambassador.

The parrot in the paradise vignette has a specific function. It serves to draw the viewer's attention to the cardinal's coat of arms and to the play of the author of the map with a host of interrelated meanings. The parrot on the Tree of Knowledge also appears to celebrate Carvajal as Spain's envoy to paradise. As Spain's ambassador to the Vicar of Christ, Carvajal was the ardent promoter of the crusade against Islam in Africa and the Middle East and of the extension of Christendom beyond the ocean, shown on the extreme left of the map. Carvajal's coat of arms in paradise would also have served to associate him with Enoch and Elijah, the two Old Testament prophets destined to wait in the earthly paradise for the end of the world, for Carvajal was convinced that, now that the Gospel was being preached throughout the whole earth, including "the Fortunate Isles of the Atlantic," the end of the world was approaching. 59 Thus the Kunstmann II map bears witness to the fact that, while the discoveries of new lands in the Atlantic were considered part of Spanish territorial expansion in Africa, they also marked a new collaboration. After a crisis in their relationship, Spain and the pope were united in their aim of organizing a crusade against the Turks and bringing Christ to both Africa and the Indies. The anonymous author of the Kunstmann II map displays on a geographical stage the convictions that lay at the core of Carvajal's diplomatic efforts: the capacity of the Christian power formed in the Mediterranean by the Catholic sovereigns not only to overcome the Turkish threat but also to follow Christ's invitation to widen 
the boundaries of the Christian world, beyond the Atlantic as well as in Africa. As a knight hangs his shield when resting after victory, or as a challenge to other knights to joust, Carvajal's coat of arms hanging on the Tree of Knowledge would seem to be highlighting his diplomatic victories as well as the challenge of a New World.

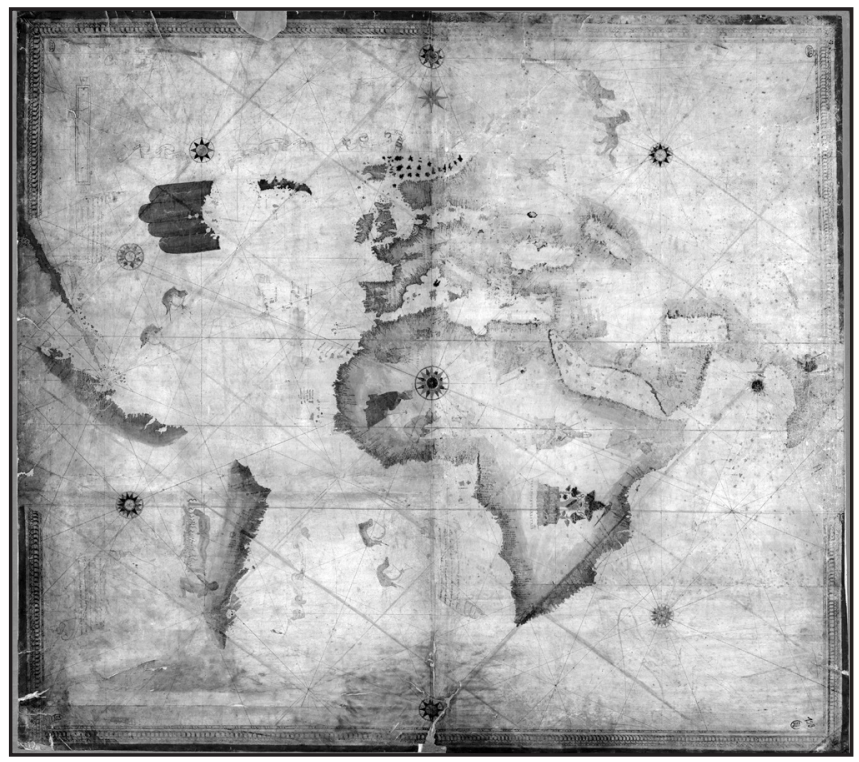

Figure 1. "Kunstmann II map", 1502-6. ?Italy. Munich. Bayerische Staatsbibliothek. Abteilung für Handschriften und Seltene Drucke. Cod. icon. 133, $99 \times 110.5 \mathrm{~cm}$. By permission of the Bayerische Staatsbibliothek. 
The African Paradise of Cardinal Carvajal 21

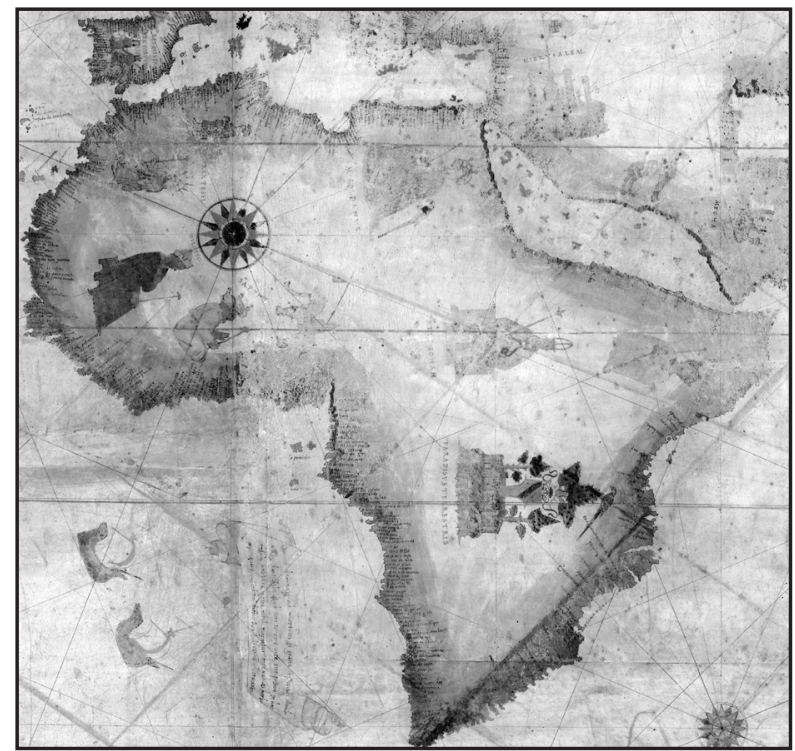

Figure 2. Detail of Figure 1: Africa.

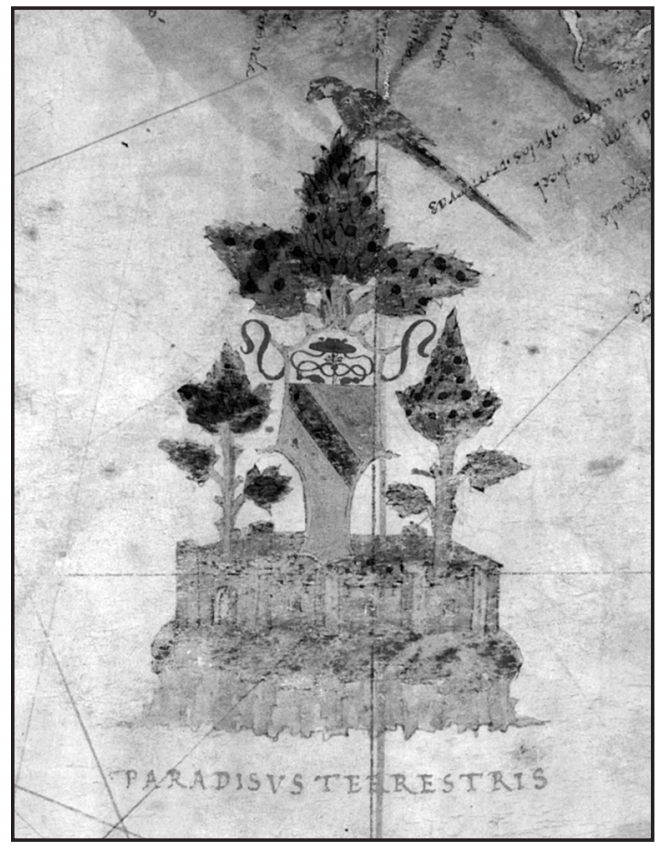

Figure 3. Detail of Figure 1: The earthly paradise in Africa. 
22 ALESSANDRO SCAFI

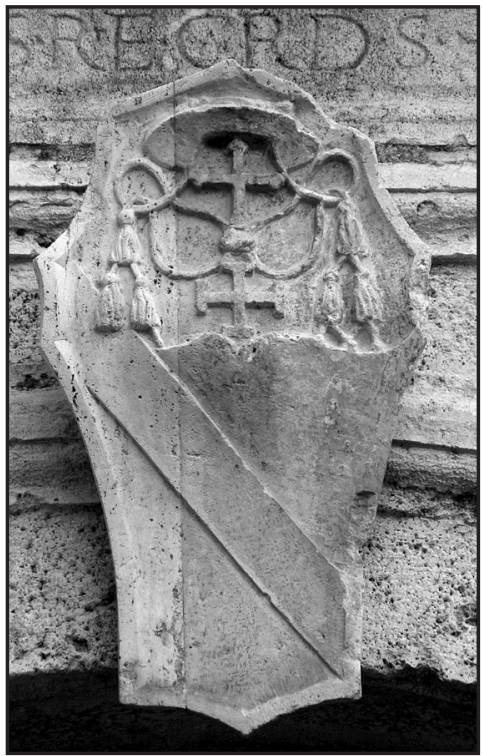

Figure 4a. Coat of arms over the entrance of Villa d'Este, Tivoli. Photograph by the author.

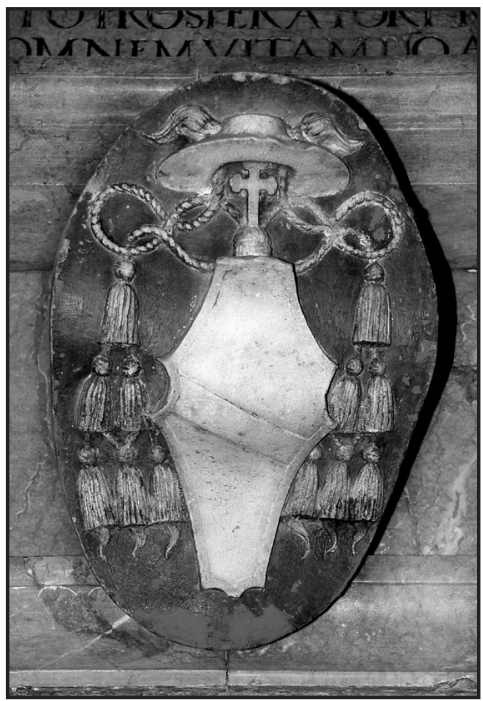

Figure 4 b. Coat of arms from the tomb of Cardinal Bernardino López de Carvajal, Rome, church of Santa Croce in Gerusalemme. Photograph by the author. 


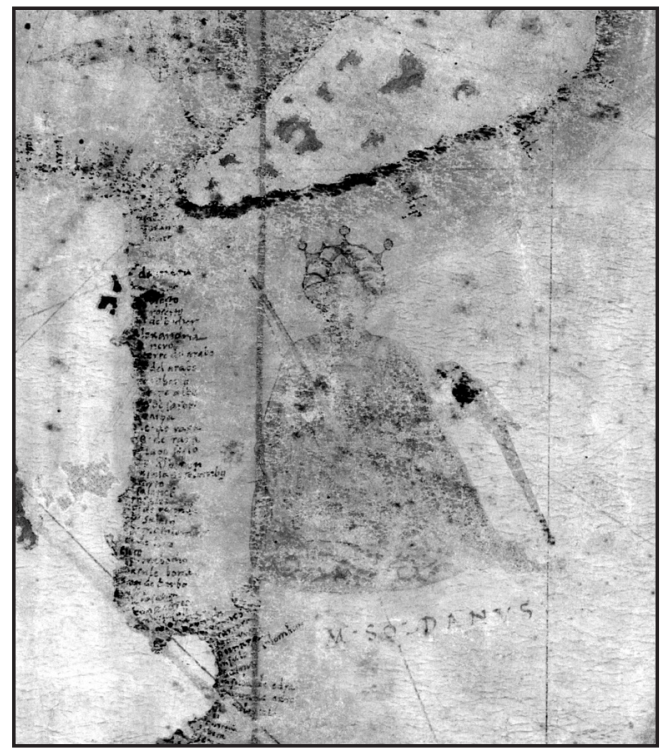

Figure 5. Detail of Figure 1: The Sultan of Babylon.

\section{Notes}

1. Munich, Bayerische Staatsbibliothek, Abteilung für Handschriften und Seltene Drucke. Cod. icon. 133. See M. Reuter, “Beschreibung der Handschrift Cod.icon. 133," in BSB-CodIcon Online. Elektronischer Katalog der Codices iconographici monacenses der Bayerischen Staatsbibliothek München (Fri Feb 29 14:32:58 CET 2008), and I. Kupčic, Münchener Portolankarten «Kunstmann I-XIII» und zehn weitere Portolankarten (Munich-Berlin: Deutscher Kunstverlag, 2000), pp. 28-34, both with bibliographies. I am grateful to Leon Conrad, Catherine Delano-Smith, Christopher Ligota, and Kate Lowe for their help in writing this essay, and to Maria Cristina Sintoni for help in interpreting Carvajal's coat of arms and the four finger-strips. I would also like to acknowledge the help of David Chambers, Brigitte Gullath, and Nelson H. Minnich, as well as Guido Buldrini, Maurizio C. A. Gorra, and Ferrante Mancini Lucidi, of the Istituto Araldico Genealogico Italiano.

2. R. Levillier, "New Light on Vespucci's Third Voyage: Evidence of his Route and Landfalls," Imago Mundi 11 (1954), pp. 37-46.

3. F. Kunstmann, K. von Sprunner, and G. M. Thomas, ed., Die Entdeckung Amerikas (Munich: Königliche Akademie der Wissenschaften, 1859), p. 127; J.-Th.-E. Hamy, "Notice sur une mappemonde portugaise anonyme de 1502, récemment découverte à Londres," Bulletin de Géograhie historique et descriptive 4 (1886); repr. Acta Cartographica 1 (1967), Plate vi; K. Kretschmer, Die Entdeckung Amerikas in ihrer Bedeutung für die Geschichte des Weltbildes (Berlin-London-Paris: [n.p.], 1892), Plate viII/2. 
4. H. Wolff, "Die Münchener Portolankarten einst und heute. The Munich Portolan Charts: Past and Present," in America: Das frühe Bild der Neuen Welt. America. Early Maps of the New World (Munich: Prestel, 1992), p. 134; Kupčic, p. 30.

5. M. Bini, E. Milano, A. Bettini, L. Federzoni, Alla scoperta del mondo: L'arte della cartografia da Tolomeo a Mercatore (Modena: Il Bulino, 2001), p. 106.

6. P. Gautier Dalché, "Le Paradis aux antipodes? Une distinctio divisionis terre et paradisi deliciarum (XIV siècle)," in «Liber largitorius»: Études d'histoire médiévale offertes à Pierre Toubert par ses élèves, ed. D. Barthélemy and J.-M. Martin (Geneva: Droz, 2003), p. 636, n. 57; F. Relaño, "Paradise in Africa: The History of a Geographical Myth from its Origins in Medieval Thought to its Gradual Demise in Early Modern Europe," Terre incognitae: The Journal for the History of Discoveries 36 (2004), p. 9.

7. The equator and the two tropics are not named and, as many scholars have noticed, their delineation does not correspond precisely to the latitudes usually attributed to them.

8. A. Scafi, Mapping Paradise: A History of Heaven on Earth (London: British Library, 2006), pp. 47-9, 125-31, 254-77.

9. Scafi, pp. 170-82, 193-5.

10. P. Schneider, L'Éthiopie et l'Inde: Interférences et confusions aux extrémités du monde antique (VIII ${ }^{e}$ siècle avant J.-C.-Vie siècle après J.-C.) (Rome: École française de Rome, 2004), pp. 53-56; see also A. Monique, Le commencement du livre: Genèse I-v. La version grecque de la Septante et sa réception (Paris: Beauchesne, 1988), pp. 193-99; for the tripartite division of India see F. Relaño, The Shaping of Africa: Cosmographic Discourse and Cartographic Science in Late Medieval and Early Modern Europe (Aldershot: Ashgate, 2002), pp. 53-55.

11. Jordan of Sévérac, Mirabilia descripta, in Indien und Europa im Mittelalter, ed. W. Baum and R. Senoner (Klagenfurt: Kitab, 2000), p. 136. The literature on Prester John is vast: for a survey see Scafi, p. 246 n. 71; see also Relaño, The Shaping of Africa, pp. 51-74.

12. F. Zarncke, ed., "Der Priester Johannes," Abhandlungen der philologisch-historischen Classe der königlich sächsischen Gesellschaft der Wissenschaften 7 (1879), pp. 912-13.

13. On the classical description of Ethiopia and later European perceptions of the country, see the synthesis in R. Pankhurst, "Ethiopia Revealed: Merchants, Travellers and Scholars," in African Zion: The Sacred Art of Ethiopia (New Haven-London: Yale University Press, in ass. with InterCultura, Fort Worth; The Walters Art Gallery, Baltimore; The Institute of Ethiopian Studies, Addis Ababa, 1993), pp. 18-31.

14. The Kunstmann map was by no means the first to locate paradise in Africa, as several fifteenth-century maps had already done so: Scafi, pp. 218-30.

15. El libro del conoscimiento de todos los reinos (The Book of Knowledge of all Kingdoms), ed. and trans. N. F. Marino (Tempe, Az: Arizona Center for Medieval and Renaissance Studies, 1999), p. 57: “ ... Nilo, el qual nasçe de las altas sierras del polo Antartico do dizen que es el Paraisso Terrenal.”

16. El libro del conoscimiento, p. 63; see also Gautier Dalché, p. 635. 
17. G. E. de Zurara, Chronique de Guinée (1453), trans. L. Bourdon and others (Paris: Chandeigne, 1994), p. 180.

18. A. von Harff, Pilgerfahrt, in The Pilgrimage of Arnold von Harf, ed. M. H. Letts (London: Hakluyt Society, 1946), pp. 173-75, 228. Von Harff also referred to the belief, held by Syrians, Abyssinians, Georgians, and others, that the garden of Eden had been located in the Holy Land.

19. On Pérez's life and work, see Wilfrid Werbeck, Jacobus Pérez von Valencia: Untersuchungen zu seinem Psalmenkommentar (Tübingen: J.C.B. Mohr, 1959), esp. pp. 1-45. Pérez drew on a variety of sources, including Augustine and rabbinical literature.

20. Jacob Pérez de Valencia, Expositiones in Psalmos Davidicos (Paris: N. de Pratis: 1521), fols ccxxiIIv-CCXxivv. See W. G. L. Randles, “The Evaluation of Columbus' 'India' Project by Portuguese and Spanish Cosmographers in the Light of the Geographical Science of the Period," Imago Mundi 42 (1990), pp. 53-54; Randles, De la terre plate au globe terrestre: Une mutation épistémologique rapide, 1480-1520 (Paris: Armand Colin, 1980), pp. 21-26.

21. Pérez, Expositiones in Psalmos, fols CLXV-CLXVI, CLV-CLVI.

22. Pérez, Expositiones in Psalmos, fol. CLVv: "philosophi nostri, quorum notitia pervenit usque ad montem lunae, per xv gradus ultra aequinoctialem, unde decurrunt fontes Nili."

23. Duarte Pacheco Pereira, Esmeraldo de situ orbis, I.2, trans. G. H. T. Kimble (London: Hakluyt Society, 1937), p. 11; See also J. Barradas de Carvahlo, À la recherche de la specificité de la Renaissance portugaise: L' "Esmeraldo de situ orbis" de Duarte Pacheco Pereira et la litterature portugaise de voyages à l'époque des grandes découvertes, 2 vols (Paris: Fondation Calouste Gulbenkian-Centre Culturel Portugais), 1983, vol. 1, p. 426.

24. See, for example, Pérez, Expositiones in Psalmos, fol. ccxxvr.

25. The Kunstmann II map is an important example of how nautical chart making adopted the logic of medieval world maps in the representation of central and southern Africa: see Relaño, The Shaping of Africa, pp. 98-100.

26. Pliny, Naturalis historia, X.58.117; see B. T. Boehrer, Parrot Culture: Our 2,50o-yearlong fascination with the world's most talkative bird (Philadelphia: University of Pennsylvania Press, 2004), pp. 5 and 29-31.

27. On the Cantino map of 1502, for instance, parrots appear in South America and West Africa. A legend in South America on the Kunstmann II map refers to the presence of parrots there. Both legend and picture refer to cannibalism. Interestingly, the earliest accounts of the exploration associated parrots and parrot-eating with cannibalism: see Boehrer, p. 53 .

28. On the praise of the parrot in ancient and medieval writers, such as Statius, Petronius, Mandeville's Travels (c. 1357-66) (where the kingdom of Prester John is described as full of "popinjays" speaking as fluently as men) and the fifteenth-century Waldensian Physiologus, see J. Dundas, "Vox Psitacci: The Emblematic Significance of the Par- 
rot," in Florilegio de Estudios de Emblemática (2004), p. 297; and Boehrer, pp. 11-12, $18,23-33$.

29. Dundas, pp. 295-96; Boehrer, pp. 10-11; R. Verdi, The Parrot in Art: From Dürer to Elizabeth Butterworth (London: Scala, 2007), pp. 12-18.

30. E. Panofsky, Problems in Titian (New York: New York University Press, 1969), p. 29.

31. This is the case, for instance, of the map by Grazioso Benincasa (1482) and the socalled Salviati map (1527-1531), on which coats of arms indicate the patron to whom the map was dedicated, respectively cardinals Raffaele Sansoni Riario and Giovanni Salviati: Florence, Biblioteca Medicea Laurenziana, Med. Pal. 249, and Bologna, Biblioteca Universitaria, Rot. 3.

32. Paolo Cortesi, De cardinalatu, II.9, in K. Weil-Garris and J. F. D'Amico, The Renaissance Cardinal's Ideal Palace: A Chapter from Cortesi's De Cardinalatu (Rome: Edizioni dell'Elefante-American Academy in Rome, 1980), pp. 94-95.

33. On Carvajal's life see G. Fragnito, “Carvajal," in Dizionario Biografico degl Italiani, XxI (Rome: Istituto dell'Enciclopedia italiana, 1978), pp. 28-34; M. Batllori, "Carvajal,” in Lexikon des Mittelalters, 9 vols (Munich-Zurich: Artemis-Winkler, 19771999), vol. 2 (1983), pp. 1535-36; A. Pacheco, “Bernardino López de Carvajal," in Contemporaries of Erasmus: A Biographical Register of Renaissance and Reformation, ed. P. G. Bietenholz and Th. B. Deutscher, 3 vols (Toronto: University of Toronto Press, 1985-1987; 2003), vol. 1, pp. 274-75; J. Goñi Gaztambide, "Bernardino López de Carvajal y las bulas alejandrinas," Anuario de Historia de l'Iglesia 1 (1992), pp. 93-112; Goñi Gaztambide, "López de Carvajal," in Diccionario de Historia Eclesiástica de España, ed. Q. Aldea Vaquero, T. Marin Martinez, and J. Vives Gatell, 4 vols (Madrid: Instituto Enrique Flórez-Consejo Superior de Investigaciones Cientificas, 1972-1975), Supplement, pp. 442-50; N. H. Minnich, "The Role of Prophecy in the Career of the Enigmatic Bernardino López de Carvajal," in Prophetic Rome in the High Renaissance Period, ed. M. Reeves (Oxford: Clarendon Press, 1992), pp. 111-20; A. Fernández de Córdova Miralles, Alejandro vi y los Reyes Católicos: Relaciones politico-eclesíasticas (1492-1503) (Rome: Edizioni Università della Santa Croce, 2005), pp. 80-90.

34. Bernardinus López de Carvajal, Oratio super praestanda solemni obedientia sanctissimo domino nostro Alexandro papae vi ex parte christianissimorum dominorumque Ferdinandi et Helisabeth, regis et reginae Hispaniae (Rome: Stephan Plannck, 1493). See H. Harrisse, "Un rarissime Americanum," Bulletin du Bibliophile (15 February 1897), 1897, pp. 5-10. On the oration, see Fernández de Córdova Miralles, pp. 83-84, 140, 171-72; 291-93, 486-91.

35. Thanks to Carvajal's diplomatic skill, the pope issued three bulls highly favourable to Spain, concerning the lands discovered by Columbus: see Fernández de Córdova Miralles, pp. 478-97, and Goñi Gaztambide, "Bernardino López de Carvajal y las bulas alejandrinas."

36. Fernández de Córdova Miralles, pp. 83, 575-76. 
37. M. Sanudo, Diarii, (Venice: Visentini, 1879-1903; repr. Bologna: Forni, 1969-1970), 58 vols, III, col. 844; quot. by Cordoba Miralles, p. 87. See also Fragnito, "Carvajal," pp. 29-30.

38. Fernández de Córdova Miralles, pp. 156, 486-87; M. Mora, Bernardino López e Carvajal: La conquista de Vaza (Granata, 1995); Goñi Gaztambide, "Bernardino López de Carvajal y las bulas alejandrinas," pp. 100-103.

39. Fernández de Córdova Miralles, pp. 202-11. The theme was also developed by contemporary humanists such as Pomponio Leto and Annio from Viterbo

40. Fernández de Córdova Miralles, pp. 170, 176-84.

41. Fernández de Córdova Miralles, pp. 465, 484, 522-526. The kingdom of Fez (as well as all lands south of cape Bojador) had been given to Portugal, with the peace of Toledo (1480). At Tordesillas, the kingdom of Fez was again given to Portugal (and Tunis to Aragon). As agreed in Tordesillas, Spain would conquer the kingdoms in north and west Africa, leaving the rest to Portugal: this is why another papal bull granted the same rights over Africa to Portugal (2 May 1497). A final settlement was reached in 1499.

42. Fernández de Córdova Miralles, pp. 175, 193, 465, 524, 528.

43. Fernández de Córdova Miralles, p. 486.

44. K. Lowe, “'Representing' Africa: Ambassadors and Princes from Christian Africa to Renaissance Italy and Portugal, 1402-1608," Transactions of the Royal Historical Society 17 (2007), p. 113; P. E. Russell, "White Kings on Black Kings: Rui de Pina and the Problem of Black African Sovereignty," in Portugal, Spain and the African Atlantic, 1343-149o: Chivalry and Crusade from John of Gaunt to Henry the Navigator, ed. P. E. Russell (Aldershot: Variorum, 1995), pp. 151-63; Z. Zafarana, "Per la storia religiosa di Firenze nel Quattrocento," Studi Medievali 9 (1968), pp. 1109-10.

45. See Fernández de Córdova Miralles, pp. 463, 508.

46. See, for instance, G. Cavallo, ed., Due mondi a confronto 1492-1728: Cristoforo Colombo e l'apertura degli spazi, 2 vols. (Rome: Istituto poligrafico e Zecca dello StatoLibreria dello Stato, 1992), vol. 2., pp. 650-53.

47. Quoted in Fernández de Córdova Miralles, p. 269.

48. Bernardinus López de Carvajal, Oratio super praestanda solemni obedientia, fol. 6v: "Subegit quoque sub eis Christus Fortunatas Insulas, quarum fertilitatem mirabilem esse constat. Ostendit et nuper alias incognitas versus Indos, quae maxime ac plene omnibus mundi preciosis existimantur, et Christo per regios internuntios brevi pariturae creduntur." Italics mine.

49. Fernández de Córdova Miralles, pp. 485, 498.

50. Fernández de Córdova Miralles, p. 172.

51. Bernardino López de Carvajal, Homelia doctissima Reverendissimi domini Cardinalis sancte Crucis, ed. G. Benignus (Rome: J. Besicken, 1508).

52. Fernández de Córdova Miralles, pp. 88, 164, 219-20.

53. Cesare Ripa, Iconologia (1618, repr. Milan: TEA, 1992), p. 116: "Il pappagallo è simbolo dell'eloquente, perché si rende meraviglioso con la lingua e con le parole imitando 
l'huomo, nella cui lingua solamente consiste l'essercitio dell'eloquenza. Et si dipinge fuora della gabbia, perché l'eloquenza non è ristretta a termine alcuno." On Carvajal as an acclaimed orator, see Fernández de Córdova Miralles, pp. 81, 87, 140, $263-65$.

54. See, for example, the maps by Angelino Dulcert (1339), Viladested (1413), Jaime Bertran (1482), Grazioso Benincasa (1482).

55. See, for example, the Catalan Atlas of 1375.

56. See Frederick II of Hohenstaufen, On the Structure and Habits of Birds, in E. Grant, A Source Book in Medieval Science (Harvard: Harvard University Press, 1974), p. 671. See also Boehrer, p. 23. Y. K. Fall, L'Afrique à la naissance de la cartographie moderne: Les cartes majorquines: $X I V^{e}-X V^{e}$ siecles (Paris: Éditions Karthala, Centre de Recherches Africaines, 1982), p. 185 and note 39, notices the presence of a parrot in the representation of the Sultan of Babylon on nautical charts but refrains from providing an explanation, only suggesting that the parrot could be a symbol of a "very old Egyptian and/or European myth" or simply "an Arabic reminiscence."

57. See Philippus Picinellus, Mundus symbolicus (Cologne: [n.p.], 1687), p. 326. The pope received the ambassadors in camera papagalli: see H. Diener, "Die 'Camera Papagalli' im Palast des Papstes: Papageien als Hausgenossen der Päpste, Könige und Fürsten des Mittelalters und der Renaissance," Archiv für Kulturgeschichte 49 (1967), pp. 4397.

58. Fernández de Córdova Miralles, pp. 530, 537.

59. Minnich, p. 115 . 